\title{
Artikel
}

\section{Evenementenvergunning: is bij concurrerende aanvragen sprake van een schaarse vergunning?}

\author{
Mr. dr. A. (Annemarie) Drahmann*
}

\section{Inleiding}

Stel: een carnavalsvereniging en een partycentrum hebben allebei verzocht om een carnavalstent te mogen plaatsen gedurende dezelfde carnavalsperiode op hetzelfde plein. Het plaatsen van twee tenten op het plein zou een gevaar kunnen vormen voor de openbare veiligheid. De burgemeester kan daarom maar een van de twee aanvragen honoreren. ${ }^{1}$ Is in die situatie sprake van een schaarse evenementenvergunning? Het antwoord op deze vraag is van belang, omdat de Afdeling bestuursrechtspraak van de Raad van State (hierna: de Afdeling) heeft geoordeeld dat op grond van het gelijkheidsbeginsel bij de verdeling van schaarse vergunningen in beginsel mededingingsruimte moet worden geboden. ${ }^{2}$

In deze bijdrage staat de vraag centraal of, en zo ja wanneer, een evenementenvergunning kan worden aangemerkt als een schaarse vergunning, en - bij een bevestigend antwoord op die vraag - hoe die schaarse evenementenvergunning dan moet worden verleend met inachtneming van het gelijkheidsbeginsel. Hiertoe zal eerst een algemene introductie worden gegeven op de regels die gelden voor evenementen, namelijk de evene-

Mr. dr. A. Drahmann is universitair (hoofd)docent aan de afdeling staats- en bestuursrecht van de Universiteit Leiden.

1. Vgl. Rb. Oost-Brabant 19 januari 2018, ECLI:NL:RBOBR:2018:279.

2. ABRvS 2 november 2016, ECLI:NL:RVS:2016:2927, AB 2016/426 m.nt. C.J. Wolswinkel, BR 2017/5 m.nt. C.A.H. van de Sanden, BR 2017/23 m.nt. E.W.J. de Groot en M. Vidal, Gst. 2017/55 m.nt. A. Drahmann, JB 2017/1 m.nt. L.J.M. Timmermans. mentenvergunning uit de Algemene Plaatselijke Verordening (APV) en het bestemmingsplan (par. 2). Vervolgens zal worden ingegaan op de vraag of, en zo ja wanneer, sprake is van een schaarse evenementenvergunning (par. 3). In paragraaf 4 en 5 wordt ten slotte stilgestaan bij de vraag welke regels er in het algemeen gelden voor de verlening van schaarse vergunningen op grond van de Dienstenrichtlijn en het nationaal recht, en hoe deze regels zouden kunnen worden toegepast bij de verlening van evenementenvergunningen.

\section{Introductie van het wettelijk kader voor evenementen}

Voor een evenement is vaak een evenementenvergunning vereist. Daarnaast zal het gebruik voor een evenement vaak ook planologisch moeten worden toegestaan. Het wettelijk kader van deze twee toestemmingen zal hierna kort worden beschreven. ${ }^{3}$

\subsection{Evenementenvergunning in de APV}

Voor evenementen is op grond van de APV vaak een vergunning vereist. Voor welke evenementen een vergunning nodig is en aan welke eisen een aanvraag moet voldoen, kan per gemeente verschillen. Hierna zal kort de vergunningplicht worden beschreven zoals deze volgt

3. Eventuele privaatrechtelijke toestemming - bijvoorbeeld omdat de gemeente ook grondeigenaar is van het terrein - wordt in dit artikel buiten beschouwing gelaten. 
uit de model-APV van de Vereniging van Nederlandse Gemeenten (VNG). ${ }^{4}$

Een evenement is 'elke voor publiek toegankelijke verrichting van vermaak', met uitzondering van de in art. 2:24 van de model-APV genoemde uitzonderingen. Onder evenementen vallen niet alleen braderieën, optochten, feesten en muziekvoorstellingen, maar ook straatfeesten en buurtbarbecues. Voor 'kleine evenementen' is geen evenementenvergunning vereist. Kleine evenementen moeten aan diverse criteria voldoen, waaronder dat zij eendaags zijn, het aantal aanwezigen beperkt is ${ }^{5}$ en geen muziek ten gehore wordt gebracht na 23.00 uur. Voor overige evenementen is op grond van art. 2:25 van de model-APV een vergunning van de burgemeester vereist. Voor de vergunningprocedure zijn geen bijzondere regels in de APV opgenomen, waardoor de algemene bepalingen uit hoofdstuk 1 van de APV gelden. Dit betekent op grond van art. 1:8 APV dat de vergunning in ieder geval moet worden geweigerd in het belang van de openbare orde, de openbare veiligheid, de volksgezondheid en de bescherming van het milieu. In de toelichting bij de model-APV wordt erop gewezen dat de burgemeester beleidsregels kan vaststellen. Het doel van een evenementenbeleid is enerzijds het vastleggen van wat er met betrekking tot evenementen in een gemeente wordt nagestreefd in relatie tot de APV, en onder welke voorwaarden dit is toegestaan. Anderzijds behelst het beleid de afstemming van processen binnen de vergunningverlening, zodat deze zo efficiënt en goedkoop mogelijk kan plaatsvinden. Het is niet ongebruikelijk dat de burgemeester het evenementenbeleid mede vormgeeft door middel van een evenementenkalender. ${ }^{6}$ Op deze kalender worden kleine evenementen die zijn aangemeld, jaarlijks terugkerende evenementen en aangevraagde evenementenvergunningen geplaatst. Zo hebben bijvoorbeeld in Boxmeer jaarlijks terugkerende evenementen die altijd op dezelfde dag plaatsvinden in principe voorrang op andere evenementen. Ook hebben evenementen van niet-commerciële partijen in principe voorrang op evenementen van commerciële partijen. Door middel van het evenementenbeleid wordt beoogd om, in het kader van leefbaarheid, grote evenementen te spreiden. ${ }^{7}$ Een ander voorbeeld is het evenementenbeleid van de gemeente Leiden. In deze gemeente hanteert de burgemeester de volgende prioriteitsvolgorde bij evenementenvergunningverlening: (1) bepaalde bij naam genoemde organisaties en evenementen, zoals de Oranjevereniging op Koningsdag, (2) evenementen met eve- nementensubsidie, (3) oud voor nieuw en (4) loting. ${ }^{8}$ Nadat een vergunning op basis van deze rangorde is verleend, wordt deze op de evenementenkalender geplaatst.

\subsection{Het bestemmingsplan}

Evenementen vinden vaak plaats op vaste plaatsen in een gemeente, bijvoorbeeld een evenemententerrein of dorpsplein. In dergelijke gevallen zal het (mede)gebruik van die locatie in het bestemmingsplan moeten worden vastgelegd. Uit een oogpunt van ruimtelijke aanvaardbaarheid - met name van het woon- en leefklimaat - zal daarbij onder meer het toegestane aantal evenementen per jaar moeten worden vastgelegd. De beoordeling en afweging van de ruimtelijke aanvaardbaarheid is een andere dan die op grond waarvan een evenementenvergunning wordt verleend. Regulering van evenementenvergunningen in de APV geschiedt immers met name vanuit het oogpunt van handhaving van de openbare orde, en waarborgt niet de vereiste planologische rechtszekerheid. ${ }^{9}$

Alleen als het om kortdurend en incidenteel gebruik van gronden voor een evenement gaat, is geen sprake van gebruik in strijd met het bestemmingsplan. Dit mag echter alleen in uitzonderlijke gevallen worden aangenomen. Het evenement Amsterdam Open Air 2013, dat plaatsvond in een recreatiegebied, viel bijvoorbeeld niet onder de uitzondering van 'kortdurend en incidenteel gebruik', omdat het evenement inclusief op- en afbouw langer duurde dan twee dagen. ${ }^{10}$ Een evenement - het Preuvenement in Kelpen-Oler - dat plaatsvond op een klein parkeerterrein van negen parkeerplaatsen, dat slechts enkele uren duurde en eenmalig zou zijn (althans ten tijde van de beslissing op het handhavingsverzoek was het college er niet van op de hoogte dat het een jaarlijks terugkerend evenement zou gaan worden), betrof volgens de Afdeling wel kortdurend en incidenteel gebruik dat niet in strijd was met het bestemmingsplan. ${ }^{11}$ Als geen sprake is van kortdurend en incidenteel gebruik, zal een omgevingsvergunning voor strijdig gebruik moeten worden aangevraagd naast de evenementenvergunning. Op grond van de 'kruimelgevallenregeling' van het Besluit omgevingsrecht (Bor) kan voor evenementen een omgevingsvergunning worden verleend. ${ }^{12}$
4. Geconsolideerde tekst model-APV, versie 'zomer 2018'

5. Wat het maximumaantal personen is dat aanwezig mag zijn bij een klein evenement, moet volgens de model-APV lokaal worden vastgesteld. Dit kan gebeuren in samenspraak met de politie en/of hulpdiensten zoals de brandweer en de ambulancedienst.

6. Zie bijvoorbeeld de Nota evenementen gemeente Boxmeer 2018, onder meer te vinden op https://praktijkvoorbeelden.vng.nl/databank/recht/ evenementen/nota-evenementen-2018.aspx.

7. Zie bijvoorbeeld de Nota evenementen gemeente Boxmeer 2018, onder meer te vinden op https://praktijkvoorbeelden.vng.nl/databank/recht/ evenementen/nota-evenementen-2018.aspx.
8. Art. 6 van de Beleidsregel van de burgemeester van de gemeente Leiden houdende regels omtrent evenementenvergunningen Beleidsregels evenementenvergunningen 2017.

9. ABRvS 11 juli 2018, ECLI:NL:RVS:2018:2340, waarin wordt verwezen naar ABRvS 20 juni 2012, ECLI:NL:RVS:2012:BW8858.

10. ABRvS 1 juli 2015, ECLI:NL:RVS:2015:2026, JM 2015/147 m.nt. J.S. Haakmeester.

11. ABRvS 15 oktober 2014, ECLI:NL:RVS:2014:3702, BR 2015/4 m.nt. C.N.J. Kortmann.

12. Art. 2.12, eerste lid, onder a, sub 2, Wabo jo. art. 4, elfde lid, van Bijlage II Bor. 


\section{Schaarste bij evenementen?}

\subsection{Inleiding: een impliciet plafond}

In het in de inleiding gegeven voorbeeld van het carnavalsfeest moet de burgemeester een keuze maken tussen twee aanvragen. In een dergelijk geval rijst de vraag of sprake is van een 'schaarse vergunning'. Dit is relevant, omdat als sprake is van een schaarse vergunning in beginsel potentiële aanvragers in de gelegenheid moeten worden gesteld om mee te kunnen dingen naar die schaarse vergunning. Deze verplichting voor bestuursorganen om mededingingsruimte te creëren vloeit voort uit zowel het Europese als het nationale recht. Welke verplichtingen dit precies betreft, zal in de volgende paragraaf worden besproken. Eerst zal worden ingegaan op de vraag of, en zo ja wanneer, een evenementenvergunning schaars is.

Van een schaarse vergunning is zonder meer sprake als het wettelijk voorschrift een expliciet maximum stelt aan het antal vergunningen dat kan worden verleend. In de uitspraak Vlaardingen, waarin de verplichting om mededingingsruimte te creëren bij schaarse vergunningen voor het eerst expliciet is benoemd, was sprake van een gemeentelijke verordening die het aantal beschikbare exploitatievergunningen voor een speelautomatenhal beperkte tot één. Voorafgaand aan deze uitspraak heeft staatsraad advocaat-generaal Widdershoven een conclusie geschreven. In deze uitspraak gaat hij in op het begrip 'schaarse vergunningen'. Volgens hem is sprake van schaarse publieke rechten 'als de som van de omvang van de aanvragen het antal beschikbare publieke rechten overtreft'. Het antal beschikbare publieke rechten moet dus beperkt zijn. Dat plafond kan voortvloeien uit de schaarste aan beschikbare natuurlijke hulpbronnen (fysieke schaarste) of aan bruikbare technische mogelijkheden (technische schaarste), maar kan ook om beleidsmatige redenen worden vastgesteld. ${ }^{13}$ In aanvulling op deze omschrijving is van belang dat de verplichting om mededingingsruimte te bieden, geldt zodra er een plafond is. Op dat moment is sprake van potentiële schaarste en zal het bestuursorgaan zich moeten afvragen hoe het de schaarse vergunningen zal gaan verdelen als de schaarste zich ook daadwerkelijk zal voordoen. Kortom: als er meer aanvragen kunnen worden ingediend dan er verleend kunnen worden, is mijns inziens sprake van een schaarse vergunning.

Met betrekking tot de evenementenvergunning doet zich de complicerende factor voor dat in de APV niet een maximum aan het aantal vergunningen is gesteld. Er is dus geen sprake van een expliciet plafond. Dat doet er echter niet aan af dat ook sprake kan zijn van een 'ver-

13. ABRvS 2 november 2016, ECLI:NL:RVS:2016:2927, AB 2016/426 m.nt. C.J. Wolswinkel. stopt' of impliciet plafond. ${ }^{14}$ Daarnaast kan nog onderscheid worden gemaakt tussen 'schaarse vergunningen' en 'vergunningen met schaarse effecten'. Bij vergunningen met schaarse effecten wordt volgens Van Es en Wolswinkel vooraf geen vergunningenplafond vastgesteld, maar worden achteraf, bij het beslissen op de individuele aanvragen, vergunningen geweigerd omdat reeds een bepaald aantal vergunningen is verleend. ${ }^{15}$

\subsection{Drie situaties van schaarste bij evenementenvergunningverlening}

Als wordt gekeken naar de evenementenvergunning, dan zal meestal geen sprake zijn van een situatie waarbij de burgemeester een keuze moet maken tussen aanvragen: evenementen zullen vaak verspreid over het jaar en/of op verschillende plaatsen plaatsvinden. Toch kunnen zich (ten minste) drie situaties voordoen waarbij mogelijk wel sprake is van schaarse vergunningverlening.

Ten eerste is het mogelijk dat in het evenementenbeleid een maximum an het antal vergunningen is gesteld. Hoewel in dat geval het vergunningenplafond niet is opgenomen in de APV, maar in beleidsregels, is mijns inziens nog altijd sprake van een duidelijk plafond en daarmee van een schaarse vergunning. De burgemeester zal immers overeenkomstig zijn beleid moeten handelen, tenzij dat voor één of meer belanghebbenden gevolgen zou hebben die wegens bijzondere omstandigheden onevenredig zijn in verhouding tot de met de beleidsregel te dienen doelen. ${ }^{16}$ Juist vanwege het bijzondere karakter van een schaarse vergunning, waarbij het bieden van gelijke kansen aan potentiële aanvragers een belangrijke rol speelt, bestaat er in beginsel geen ruimte om in individuele gevallen uitzonderingen toe te staan. ${ }^{17}$ Ten tweede is het mogelijk dat een aanvraag voor een evenementenvergunning wordt ingediend, terwijl al een vergunning is verleend voor dezelfde plaats op hetzelfde moment. De vergunning kan dan worden geweigerd, omdat een vergunning voor het evenement in deze vorm niet in het belang van de openbare orde of de openbare veiligheid is. In dat geval is sprake van een 'vergunning met schaarse effecten'. Zoals Van Es en Wolswinkel terecht opmerken, zijn de gevolgen van deze vergunningen met schaarse effecten vergelijkbaar met die van schaarse vergunningen. De latere aanvrager zal immers geen evenement kunnen organiseren, ook al voldoet hij aan de (overige) criteria voor vergunningverlening.

14. Vgl. F.J. van Ommeren, W. den Ouden \& C.J. Wolswinkel, Schaarse publieke rechten: naar een algemeen leerstuk, in: F.J. van Ommeren, W. den Ouden \& C.J. Wolswinkel (red.), Schaarse publieke rechten, Den Haag: Boom Juridische uitgevers 2011, p. 20, waarbij als voorbeeld van een verstopt plafond wordt verwezen naar de bijdrage van Van Rijswick 'De verdeling van schaarse waterrechten' in dezelfde bundel.

15. M.M. van Es \& C.J. Wolswinkel, Tussen schaarste en open einde. Eisen aan de verlening van vergunningen met schaarse effecten, Gst. 2015/51.

16. Art. $4: 84 \mathrm{Awb}$

17. Vgl. ABRvS 24 april 2013, ECLI:NL:RVS:2013:BZ8429, AB 2013/327 m.nt. C.J. Wolswinkel (MFS II-subsidie). Zie tevens C.J. Wolswinkel, Schaarse publiekrechtelijke rechten: een algemeen leerstuk gerelativeerd, NTB 2014/7. 
Mijns inziens kan worden gesteld dat ook in dat geval sprake is van een schaarse vergunning, omdat sprake is van een impliciet vergunningenplafond. De eerste vergunning is daarbij verleend op basis van het verdeelsysteem 'wie het eerst komt, het eerst maalt'.

Ten derde is het mogelijk dat - zoals het voorbeeld in de inleiding - twee aanvragen vrijwel tegelijkertijd worden ingediend en de burgemeester moet kiezen welke aanvraag hij zal inwilligen en welke hij zal afwijzen. De grondslag voor de verplichting om mededingingsruimte te creëren is gelegen in het gelijkheidsbeginsel, dat in deze context strekt tot het bieden van gelijke kansen. Zodra een bestuursorgaan zich geconfronteerd ziet met een situatie waarbij hij uit meerdere aanvragen er slechts één of enkele kan inwilligen en de overige moet afwijzen, doet zich mijns inziens een situatie voor waarbij sprake is van de verdeling van schaarse publieke rechten: de som van de omvang van de aanvragen overtreft immers het antal beschikbare publieke rechten. Het bestuursorgaan zal dan worden geconfronteerd met verdelingsvragen die zien op het bieden van gelijke kansen aan de aanvragers.

In het gegeven voorbeeld van het carnavalsfeest oordeelde de voorzieningenrechter echter dat geen sprake was van een schaarse vergunning. De voorzieningenrechter stelt weliswaar vast dat er sprake is van concurrerende aanvragen, maar oordeelt dat het niet om een schaarse vergunning gaat, omdat het geen situatie is waarin sprake is van een vooraf kenbaar, beperkt aantal beschikbare vergunningen, en omdat het eenieder vrijstaat om op hetzelfde moment op een andere daartoe geschikte locatie een vergelijkbaar evenement te organiseren. ${ }^{18}$ De voorzieningenrechter gaat er daarbij echter aan voorbij dat een bestuursorgaan in beginsel gehouden is om te beslissen op de aanvraag zoals deze is ingediend. Het feit dat er wellicht ook andere locaties zijn om een carnavalsfeest te organiseren, doet er niet aan af dat er twee aanvragen zijn ingediend voor dezelfde locatie. De vraag doet zich daarbij voor waarom de ene aanvraag de voorkeur verdient boven de andere aanvraag, en welke criteria daarbij zijn gehanteerd. In de uitspraak over het carnavalsfeest had de burgemeester tijdens de zitting uiteengezet waarom de evenementenvergunning is verleend aan De Pintewippers. De aanvraag van de Pintewippers was eerder, maar dat was niet doorslaggevend. Volgens de burgemeester was De Pintewippers de meest aangewezen partij, omdat zij al jaren ervaring heeft met het organiseren van de vele festiviteiten rondom carnaval. De voorzieningenrechter is van oordeel dat - gelet op de beoordelingsvrijheid die de burgemeester heeft de burgemeester voldoende heeft gemotiveerd waarom de evenementenvergunning aan De Pintewippers is verleend. Gelet op de criteria die de Afdeling in de Vlaardingen-uitspraak heeft gegeven voor de verdeling van schaarse vergunningen, had de burgemeester echter mijns inziens vooraf beleidsregels moeten opstellen waarin wordt aangegeven hoe met concurrerende aan-

18. Rb. Oost-Brabant 19 januari 2018, ECLI:NL:RBOBR:2018:279. vragen zal worden omgegaan. Dit zou ook in lijn zijn met een uitspraak van de Afdeling uit 2012 over Koninginnenacht in Den Bosch. De Afdeling oordeelde dat de weigering om een evenementenvergunning te verlenen ondoorzichtig tot stand was gekomen. Ook in die situatie moest het bestuur een keuze maken tussen concurrerende evenementen. Het ontbreken van kenbare maatstaven bij de beslissing om een evenement op de evenementenkalender te plaatsen en de evenementenvergunning te verlenen droeg eraan bij dat de besluiten op onzorgvuldige wijze tot stand waren gekomen. ${ }^{19}$ Deze uitspraak van de Afdeling dateert van voor de Vlaardingen-uitspraak. Mijn inschatting is dat de Afdeling thans zou oordelen dat sprake is van een schaarse vergunning en dat de besluitvorming, vanwege het ontbreken van verdelingsbeleid, in strijd is met het gelijkheidsbeginsel en de daaruit voortvloeiende transparantieverplichting. Op de vraag hoe aan deze verplichting kan worden voldaan, wordt in paragraaf 4 ingegaan.

\subsection{Geen schaarse vergunning als het mogelijk is om vergunningvoorschriften te stellen}

Als meerdere aanvragen voor een evenementenvergunning voor dezelfde locatie en tijd worden ingediend, zal allereerst moeten worden bezien of het mogelijk is om door middel van vergunningvoorschriften alle aanvragen te honoreren. Daarbij kan onderscheid worden gemaakt tussen een anvraag die wordt ingediend als al een vergunning is verleend en de situatie dat meerdere aanvragen nog aanhangig zijn.

Als al eerder een vergunning is verleend, kunnen parallellen worden gemaakt met de vergunning voor een bodemenergiesysteem. Art. 6.11 van het Waterbesluit bepaalt dat het bevoegd gezag aan een vergunning zodanige voorschriften verbindt dat het in werking hebben van een open bodemenergiesysteem niet leidt tot zodanige interferentie met een eerder geïnstalleerd bodemenergiesysteem, dat het doelmatig functioneren van een van de desbetreffende systemen kan worden geschaad. De Rechtbank Noord-Holland heeft recent geoordeeld dat uit dit artikel het beginsel 'wie het eerst komt, het eerst pompt' volgt. Uit het artikel volgt niet dat een tweede aanvraag niet tot vergunningverlening mag leiden indien een eerdere aanvraag kan worden ingewilligd, omdat verlening van meer vergunningen voor dezelfde locatie mogelijk is. Door middel van vergunningvoorschriften kan negatieve interferentie van bodemenergiesystemen worden voorkomen. ${ }^{20}$ Voor de evenementenvergunning kan eenzelfde redenering worden gevolgd: als meerdere evenementenvergunningen worden angevraagd, zal bij de latere aanvraag rekening moeten worden gehouden met de eerdere vergunningverlening, en moet worden bezien in hoeverre door middel van het stellen van vergunningvoorschriften ook de tweede vergunning kan worden verleend. De eerdere

19. ABRvS 22 februari 2012, ECLI:NL:RVS:2012:BV6519. Zie tevens de vervolguitspraak ABRvS 3 september 2014, ECLI:NL:RVS:2014:3274, AB 2015/293 m.nt. C.J. Wolswinkel.

20. Rb. Noord-Holland 30 juli 2018, ECLI:NL:RBNHO:2018:6586. 
vergunningverlening heeft dus een effect op de latere vergunningverlening. In die zin is er schaarste, waarbij de vergunningen worden verleend op basis van het uitgangspunt 'wie het eerst komt, het eerst maalt'.

Als op meerdere aanvragen nog niet is beslist, dan zal bezien moeten worden of het mogelijk is om beide vergunningen te verlenen door middel van vergunningvoorschriften. Illustratief in dit verband is een uitspraak over twee aanvragen voor het aanmeren met een rondvaartboot respectievelijk fietspendelboot op dezelfde aanmeerkade op dezelfde aanmeertijden. Het college van burgemeester en wethouders had beide ontheffingen verleend, hetgeen in strijd met de openbare veiligheid zou kunnen zijn. De vervolgvraag is of het college daarom een van de twee aanvragen had moeten afwijzen. De Afdeling oordeelt dat dit niet het geval is. Het college had beslissingsruimte bij het besluiten op de aanvraag. Het stond het college immers vrij om de ontheffingsaanvragen slechts gedeeltelijk in te willigen en zo alsnog te bewerkstelligen dat de aanmeertijden niet overlappen. $^{21}$ Aanmeertijden zijn aspecten die door middel van een voorschrift kunnen worden geregeld. Door het opnemen van bepaalde aanmeertijden zou dan ook niet de grondslag van de aanvraag worden verlaten. Het uitgangspunt is immers dat de burgemeester moet beslissen op de aanvraag zoals deze is ingediend. Op grondslag van de aanvraag en aan de hand van daarin aangevraagde activiteiten staat het de burgemeester vrij te beoordelen welke vergunningen of ontheffingen daarvoor nodig zijn en welke voorschriften daaraan moeten worden verbonden. ${ }^{22}$ De locatie van een evenement is mijns inziens een wezenlijk onderdeel van de aanvraag, waardoor - zonder een wijziging van die aanvraag - een evenementenvergunning niet voor een geheel andere locatie dan is aangevraagd, kan worden verleend.

Het stellen van vergunningvoorschriften kan dus soms uitkomst bieden om meerdere evenementenvergunningen te kunnen verlenen. Dit zal echter niet in alle gevallen uitkomst bieden, omdat bepaalde festiviteiten nu eenmaal op een bepaalde dag plaatsvinden en aanvragers niet altijd bereid zullen zijn om hun aanvraag te wijzigen naar een andere locatie, waardoor het afwijzen van een van de aanvragen de enige mogelijkheid voor de burgemeester is.

\subsection{Natuurlijke schaarste en beperkte ruimte}

Uit het voorgaande is gebleken dat bij de vraag of sprake is van schaarste de locatie van het evenement een belangrijke rol speelt. In dit verband is ook de recente conclusie van staatsraad advocaat-generaal Widdershoven over het windpark in Zeewolde relevant. ${ }^{23}$ Widdershoven concludeert hierin onder meer dat omgevingsvergunningen in de regel geen besluiten zijn die een schaars

21. ABRvS 22 augustus 2018, ECLI:NL:RVS:2018:2784.

22. Rb. Oost-Brabant 7 maart 2017, ECLI:NL:RBOBR:2017:1204.

23. Conclusie 6 juni 2018, ECLI:NL:RVS:2018:1847. Volledigheidshalve wordt opgemerkt dat de auteur als advocaat betrokken is geweest in deze procedure. In dit artikel wordt mede daarom volstaan met een beschrijving van de algemene bevindingen van de A-G. recht toebedelen, omdat zij doorgaans alleen kunnen worden aangevraagd door degene die over de grond kan beschikken en er voor de vergunning dus niet meer gegadigden kunnen zijn dan vergunningen. De beschikbare locatie is beperkt, niet het aantal vergunningen. De evenementenvergunning verschilt van de omgevingsvergunning omdat het geen vergunning is die betrekking heeft op de ruimtelijke ordening, maar op het belang van de openbare orde en veiligheid. Zeker omdat evenementen vaak plaatsvinden in de openbare ruimte, gaat de vergelijking met de omgevingsvergunning mank. Dit heeft tot gevolg dat er bij een evenementenvergunning wel sprake kan zijn van meer gegadigden dan vergunningen.

Ten slotte kan in het kader van schaarste nog onderscheid worden gemaakt tussen beleidsmatige en natuurlijke schaarste. Zoals gesteld, is het met name de locatie die ervoor kan zorgen dat een evenementenvergunning schaars wordt. Dit betekent echter nog niet dat sprake is van natuurlijke schaarste. Widdershoven gaat in zijn conclusie uitgebreid in op het verschil tussen beide vormen van schaarste. De achtergrond voor het onderscheid tussen beide vormen van schaarste ligt in de Dienstenrichtlijn. Beleidsmatig schaarse vergunningen zijn vergunningen waarvan het aantal is beperkt om dwingende redenen van algemeen belang, terwijl bij natuurlijk schaarse vergunningen het aantal beperkt is vanwege de schaarste van de beschikbare natuurlijke hulpbronnen of de bruikbare technische mogelijkheden. In het Promoimpresa-arrest kwam dit onderscheid aan de orde. ${ }^{24}$ Die zaak ging over een door een Italiaanse gemeente verleende 'concessie' (een vergunning in de zin van de Dienstenrichtlijn) voor de exploitatie van toeristische activiteiten op het publieke strand van het Gardameer. Het aantal concessies/vergunningen was schaars, omdat de grootte van het strand van het Gardameer beperkt is. De vraag of sprake is van natuurlijk schaarse vergunningen, wordt door het Hof van Justitie van de Europese Unie teruggelegd bij de nationale rechter. Botman wijst erop dat de advocaat-generaal Szpunar heeft betoogd dat sprake is van een schaarse natuurlijke vergunning. ${ }^{25}$ Wolswinkel wijst er daarentegen op dat op grond van art. 12 van de Dienstenrichtlijn de schaarste van het aantal vergunningen 'noodzakelijkerwijs' beperkt moet zijn door de schaarste van de natuurlijke hulpbron. ${ }^{26}$ Widdershoven volgt Wolswinkel op dit punt en constateert dat daarom aan het Gardameer geen sprake is van een natuurlijk schaarse vergunning als de vergunningen om beleidsmatige redenen maar voor een beperkt deel van de stranden aan het Gardameer worden verleend. Zowel voor omgevingsvergunningen als voor evenementenvergunningen geldt

24. HvJ EU 14 juli 2016, C-458/14 en C-67/15, ECLI:EU:C:2016:558 (Promoimpresa).

25. M.R. Botman, Kapers op de Italiaanse kust. De gevolgen van het arrest Promoimpresa voor de verdeling van schaarse rechten, Gst. 2017/3, p. 6-15.

26. C.J. Wolswinkel, Concurrerende verdelingsregimes? Schaarse vergunningen onder Unierecht en nationaal recht na Vlaardingen en Appingedam, SEW 2018/7. 
dat schaarste op zich alles te maken heeft met de beperkte ruimte (een natuurlijke hulpbron), maar zelden noodzakelijkerwijs uit de schaarste van die hulpbron zal voortvloeien. Het zijn immers beleidsmatige keuzes die bepalen of een bepaalde activiteit toelaatbaar is. In het geval van de evenementenvergunning ligt de schaarste dus niet noodzakelijkerwijs in de omvang van het plein, maar in de beleidsmatige afweging over de openbare orde en veiligheid. Op de eisen die de Dienstenrichtlijn stelt aan de verlening van schaarse vergunningen zal in de volgende paragraaf nog nader worden ingegaan.

\subsection{Tussenconclusie}

Uit het voorgaande blijkt dat bij de verlening van evenementenvergunningen soms sprake zal zijn van een schaarse vergunning. Dit zal het geval zijn als in evenementenbeleid een maximum aan het aantal vergunningen is gesteld of als er sprake is van een impliciet plafond, omdat het uit het oogpunt van openbare veiligheid niet mogelijk is om twee evenementen tegelijk op dezelfde locatie toe te staan. Als het niet mogelijk is om door middel van vergunningvoorschriften beide evenementen te vergunnen, dan is sprake van een schaars publiek recht, waarbij de evenementenvergunning slechts aan één van de aanvragers kan worden verleend.

\section{Juridisch kader voor de verdeling van schaarse vergunningen}

Als sprake is van een schaarse vergunning moeten potentiële aanvragers in beginsel in de gelegenheid worden gesteld om mee te dingen naar die schaarse vergunning. Deze verplichting voor bestuursorganen om mededingingsruimte te creëren vloeit voort uit zowel het Europese als het nationale recht. Wat deze verplichting inhoudt, zal hierna kort worden beschreven.

\subsection{Dienstenrichtlijn}

De Dienstenrichtlijn bevat regels voor de verdeling van schaarse dienstenvergunningen. De eerste vraag die in dit kader moet worden beantwoord, is of het organiseren van een evenement een dienst is. Een dienst wordt in art. 4 van de richtlijn gedefinieerd als 'elke economische activiteit, anders dan in loondienst, die gewoonlijk tegen vergoeding geschiedt, zoals bedoeld in artikel 57
VWEU' ${ }^{27}$ Het Handboek voor de implementatie van de Dienstenrichtlijn bevat een niet-uitputtende lijst van diensten. Hierin worden ook genoemd: 'diensten voor ondernemingen (waaronder kantooronderhoud, managementadviezen, organisatie van evenementen, incassodiensten, reclame- en wervingsdiensten)', 'diensten op het gebied van toerisme (waaronder diensten van reisbureaus)' en 'vrijetijdsdiensten (onder meer de diensten van sportcentra en pretparken)'. Het organiseren van een grootschalig evenement kan dan ook worden aangemerkt als een dienst in de zin van de Dienstenrichtlijn. Ook de wetgever is er bij de implementatie van de Dienstenrichtlijn in Nederland van uitgegaan dat een evenementenvergunning een dienstenvergunning is. ${ }^{28}$

De vervolgvraag is dan wie een beroep kan doen op de bepalingen uit de Dienstenrichtlijn. Sinds het Appingedam-arrest is duidelijk dat de bepalingen uit de richtlijn die zien op de vrijheid van vestiging van dienstverrichters (hoofdstuk III van de richtlijn) ook van toepassing zijn in zuiver interne situaties. ${ }^{29}$ Dat betekent dat ook een Nederlandse ondernemer kan betogen dat een bepaling uit een APV in strijd is met de Dienstenrichtlijn. ${ }^{30}$

De laatste - en belangrijkste - vraag is uiteraard wat de Dienstenrichtlijn dan bepaalt over de verdeling van schaarse vergunningen. Voor natuurlijk schaarse vergunningen bevat art. 12 van de Dienstenrichtlijn een specifieke bepaling. Op grond van dat artikel moet de selectie uit de gegadigden worden gemaakt 'volgens een selectieprocedure die alle waarborgen voor onpartijdigheid en transparantie biedt met inbegrip van met name een toereikende bekendmaking van de opening, uitvoering en afsluiting van de procedure'. Daarnaast wordt een natuurlijk schaarse vergunning voor 'een passende beperkte duur verleend en wordt zij niet automatisch verlengd'. Voor beleidsmatig schaarse vergunningen is niet een dergelijke expliciete verplichting om een

27. Art. 57 VWEU luidt als volgt: 'In de zin van de Verdragen worden als diensten beschouwd de dienstverrichtingen welke gewoonlijk tegen vergoeding geschieden, voorzover de bepalingen, betreffende het vrije verkeer van goederen, kapitaal en personen op deze dienstverrichtingen niet van toepassing zijn.

De diensten omvatten met name werkzaamheden:

a. van industriële aard,

b. van commerciële aard,

c. van het ambacht,

d. van de vrije beroepen.

Onverminderd de bepalingen van het hoofdstuk betreffende het recht van vestiging, kan degene die de diensten verricht, daartoe zijn werkzaamheden tijdelijk uitoefenen in de lidstaat waar de dienst wordt verricht, onder dezelfde voorwaarden als die welke die lidstaat aan zijn eigen onderdanen oplegt.'

28. Zo wordt de evenementenvergunning meermaals als voorbeeld genoemd in de MvT bij de Dienstenwet (Kamerstukken II 2007/08, 31579, nr. 3).

29. HvJ EU 30 januari 2018, C-360/15 en C-31/16, ECLI:EU:C:2018:44, AB 2018/181 m.nt. Nijmeijer, JB 2018/60 m.nt. Sanderink, Gst. 2018/68 m.nt. Hessel. Tevens J.C. van Oosten \& A. Drahmann, Europese dienstenrichtlijn ook van toepassing op regulering van detailhandel in bestemmingsplannen, mogelijke verzwaring motiveringslast, Bb 2018/12.

30. Zie over de gevolgen van dit arrest voor de Nederlandse praktijk onder meer J.C. van Oosten \& A. Drahmann, De gevolgen van Appingedam en Zeewolde voor het Nederlands bestuursrecht, in het bijzonder voor ruimtelijke besluiten, JBplus 2018, afl. 3. 
selectieprocedure te houden in de richtlijn opgenomen. Wel is in de richtlijn (art. 11) bepaald dat een aan een dienstverrichter verleende vergunning geen beperkte geldigheidsduur heeft, tenzij 'het aantal beschikbare vergunningen is beperkt door een dwingende reden van algemeen belang'. In het Trijber-arrest heeft het Hof van Justitie geoordeeld dat beleidsmatig schaarse vergunningen daarom altijd voor beperkte tijd verleend moeten worden. ${ }^{31}$

In de vorige paragraaf is geconcludeerd dat als een evenementenvergunning een schaarse vergunning is, dit een beleidsmatig schaarse vergunning zou zijn. Hoewel de Dienstenrichtlijn een transparante verdeelprocedure niet expliciet voorschrijft, ligt het wel in de lijn der verwachting dat het Hof van Justitie zal oordelen dat ook bij die vergunningen reële mededinging gegarandeerd moet worden. In het eerdergenoemde Trijber-arrest oordeelt het Hof van Justitie dat schaarse vergunningen voor bepaalde tijd moeten worden verleend, omdat verlening voor onbepaalde tijd afbreuk zou doen aan het doel van art. 11 van de Dienstenrichtlijn, 'te weten toegang van dienstverrichters tot de betrokken markt'. Met Widdershoven ben ik van mening dat hieruit een mededingingsverplichting kan worden afgeleid, omdat die beperkte vergunningsduur anders weinig zin heeft. ${ }^{32}$ Bovendien heeft het Hof van Justitie in het Betfairarrest geoordeeld dat de Nederlandse praktijk waarbij schaarse kansspelvergunningen automatisch werden verlengd in strijd is met de vrijheid van dienstverrichting, omdat dit in strijd is met het beginsel van gelijke behandeling en de transparantieverplichting. Volgens het Hof van Justitie is de transparantieverplichting 'een dwingende prealabele voorwaarde van het recht van een lidstaat om aan één ondernemer het exclusieve recht te verlenen om een economische activiteit te verrichten, ongeacht de wijze van selectie van deze ondernemer'. ${ }^{33}$ Deze beginselen van gelijkheid, transparantie en onpartijdigheid gelden ook voor de procedure tot verlening van beleidsmatig schaarse dienstenvergunningen. Kortom: voor zowel beleidsmatig als natuurlijk schaarse vergunningen geldt op grond van de Dienstenrichtlijn mijns inziens dat ingevolge het gelijkheidsbeginsel en de transparantieverplichting in beginsel een verdeelprocedure gehouden moet worden. Het enige verschil is dat art. 12 in meer detail bepaalt hoe die procedure er bij een natuurlijk schaarse vergunning uit moet zien.

\subsection{Een nationale mededingingsplicht: de uitspraak Vlaardingen}

Lange tijd was onduidelijk of er (ook) op grond van het nationale bestuursrecht een verplichting gold om mededingingsruimte te creëren. Eerdere jurisprudentie van de Afdeling en het College van Beroep voor het bedrijfsleven $(\mathrm{CBb})$ bood hier wel aanknopingspunten voor, maar met de Vlaardingen-uitspraak heeft de Afdeling

31. HvJ EU 1 oktober 2015, C-340/14 en C-341/14, ECLI:EU:C:2015:641.

32. Conclusie A-G in de Vlaardingen-zaak, alinea 3.10 (AB 2016/426 m.nt. C.J. Wolswinkel).

33. HvJ EU 3 juni 2010, ECLI:EU:C:2010:307. definitief duidelijkheid gegeven. In de uitspraak heeft de Afdeling geoordeeld dat in het Nederlands recht een rechtsnorm geldt die ertoe strekt dat bij de verdeling van schaarse vergunningen door het bestuur op enigerlei wijze aan (potentiële) gegadigden ruimte moet worden geboden om naar de beschikbare vergunning(en) mee te dingen'. Aan andere ondernemers moet, op het moment dat er ruimte ontstaat een vergunning te verlenen, in beginsel de mogelijkheid worden geboden mee te dingen naar de schaarse vergunning. Deze rechtsnorm is, aldus de Afdeling, gebaseerd op het gelijkheidsbeginsel dat in deze context strekt tot het bieden van gelijke kansen.

De Afdeling oordeelt verder dat uit deze rechtsnorm voortvloeit dat schaarse vergunningen in beginsel alleen tijdelijk kunnen worden verleend. De vergunninghouder wordt namelijk bij verlening voor onbepaalde tijd onevenredig bevoordeeld, omdat het voor nieuwkomers dan nagenoeg onmogelijk is om nog toe te treden tot de markt.

Ten slotte oordeelt de Afdeling dat om gelijke kansen te kunnen realiseren een bestuursorgaan een passende mate van openbaarheid moet verzekeren met betrekking tot (1) de beschikbaarheid van de schaarse vergunning, (2) de verdelingsprocedure, (3) het aanvraagtijdvak en (4) de toe te passen criteria. Het bestuursorgaan moet hierover tijdig - voorafgaand aan de start van de aanvraagprocedure - duidelijkheid scheppen door informatie over deze aspecten bekend te maken via een zodanig medium dat potentiële gegadigden daarvan kennis kunnen nemen.

Voor zover voor schaarse evenementenvergunningen uit de Dienstenrichtlijn dus nog geen verplichting om mededingingsruimte te creëren zou voortvloeien, dan geldt deze verplichting op grond van het nationale recht.

In 2013 heeft de Afdeling uitspraak gedaan over de verlening van terrasvergunningen voor de Vierdaagsefeesten in Nijmegen. Ook daar was sprake van een situatie waarbij de burgemeester een keuze moest maken tussen twee concurrerende aanvragen en voorzag de APV hier niet in. De Afdeling oordeelde dat het ontbreken van een wettelijk toetsingskader voor het maken van de keuze tot gevolg heeft dat de bestuursrechter het besluit terughoudend moet toetsen. De rechter dient zich te beperken tot de vraag of de gemaakte afweging onredelijk is dan wel anderszins in strijd met algemene beginselen van behoorlijk bestuur. De Afdeling oordeelde dat daar in dat geval geen sprake van was. ${ }^{34}$ Mijns inziens heeft de Vlaardingen-uitspraak tot gevolg dat de Afdeling thans zou oordelen dat de besluitvorming door de burgemeester in strijd was met algemene beginselen van behoorlijk bestuur, namelijk het gelijkheidsbeginsel. De burgemeester had immers geen passende mate van

34. ABRvS 25 september 2013, ECLI:NL:RVS:2013:1228, AB 2013/385 m.nt. A. Drahmann. Als de burgemeester wel evenementenbeleid vaststelt, dan worden de daarin opgenomen beoordelingsregels om te komen tot een keuze tussen concurrerende aanvragen, gelet op de beleidsvrijheid van de burgemeester, eveneens terughoudend getoetst (ABRvS 6 april 2011, ECLI:NL:RVS:2011:BQ0297 en ECLI:NL:RVS: 2011:BQ0298 (Gay Pride 2008 en 2009)). 
openbaarheid verzekerd met betrekking tot de wijze van verdeling van de schaarse (terras)vergunning.

\subsection{Samenloop tussen evenementenvergunningen en het bestemmingsplan}

Hiervoor is in paragraaf 3.3 al ingegaan op de conclusie van advocaat-generaal Widdershoven in de zaak Windpark Zeewolde. Widdershoven concludeert dat in bestemmingsplannen en omgevingsvergunningen in beginsel geen schaarse rechten worden toegedeeld. In beginsel, want op deze hoofdregel formuleert hij een aantal uitzonderingen. Twee van deze uitzonderingen kunnen voor evenementen van belang zijn.

Een van deze uitzonderingen ziet op de situatie dat er een sterke verbondenheid is tussen een schaarse (exploitatie)vergunning en een bestemmingsplan/omgevingsvergunning.

Van deze verbondenheid was sprake in Helmond. De APV van Helmond bepaalde namelijk dat er slechts één exploitatievergunning voor een speelautomatenhal beschikbaar was en dat die exploitatievergunning slechts kan worden verleend voor een speelautomatenhal die niet in strijd is met het bestemmingsplan. Vestiging van een speelautomatenhal was in Helmond niet rechtstreeks toegelaten in het bestemmingsplan. Om in aanmerking te kunnen komen voor een exploitatievergunning was dus in alle gevallen een omgevingsvergunning voor afwijking van het bestemmingsplan nodig. Vervolgens dienden twee exploitanten een aanvraag om een exploitatie- en omgevingsvergunning in. Het college van burgemeester en wethouders had de aanvragen van een van de twee exploitanten ingewilligd en daaraan ten grondslag gelegd dat de locatie van die exploitant 'vanuit ruimtelijk oogpunt bezien meer geschikt' was dan de andere locatie. De Afdeling stelde daarom vast dat het college de aanvragen om een omgevingsvergunning in samenhang met elkaar had beoordeeld, ervan uitgaande dat er ruimtelijk slechts één speelautomatenhal aanvaardbaar was. Dit had tot gevolg dat het besluit aan wie van de gegadigden een omgevingsvergunning werd verleend in dit geval mede bepaalde aan wie de exploitatievergunning zou worden verleend. De besluitvorming omtrent de omgevingsvergunning werkte hier dus als verdeelinstrument bij de toedeling van een schaars recht. Door de sterke verbondenheid tussen de APV en het bestemmingsplan dienen daarom volgens de Afdeling de uit de transparantieverplichting voortvloeiende eisen van openbaarheid die gelden bij de verdeling van een schaarse exploitatievergunning ook te gelden bij de procedure voor verlening van de omgevingsvergunning voor met het bestemmingsplan strijdig gebruik. Beide procedures dienen op elkaar te worden afgestemd. ${ }^{35}$ Widdershoven schrijft in zijn conclusie dat er drie elementen van belang zijn om de omgevingsvergunning in dit geval als schaarse vergunning te behandelen: (1) het feit dat de verlening van de (schaarse) exploitatiever- gunning waarvoor een plafond geldt, in de APV is gekoppeld aan het bestemmingsplan; (2) het feit dat het bestemmingsplan afwijking voor hoogstens één vergunning toestaat; en (3) het feit dat de motivering vergelijkend van aard is en ervan uitgaat dat beide locaties in het licht van de goede ruimtelijke ordening op zichzelf geschikt zijn voor de vestiging van de speelautomatenhal. Vanwege deze cumulatieve voorwaarden zal deze situatie zich volgens Widdershoven vermoedelijk niet vaak voordoen. ${ }^{36}$

Als gekeken wordt naar de regels die gelden voor evenementen, dan valt op dat ook voor evenementen de planologische regeling een belangrijke rol kan spelen. Een belangrijk verschil met de Helmond-uitspraak is dat in de model-APV het bestemmingsplan geen weigeringsgrond is. Mocht een gemeenteraad afwijken van dit model en wel een specifieke weigeringsgrond opnemen, dan zou wel aan de drie voorwaarden kunnen worden voldaan.

De tweede uitzondering die Widdershoven bespreekt, is dat in sommige bestemmingsplannen een maximumaantal bestemmingen is opgenomen. Hij noemt hierbij het voorbeeld van een bestemmingsplan in Alphen aan den Rijn. ${ }^{37}$ De zaak betrof twee kort na elkaar ingediende aanvragen voor een omgevingsvergunning voor het bouwen van een woning. In het bestemmingsplan was aan deze gronden de bestemming 'Woondoeleinden' met de nadere aanduiding ' 11 woningen toegestaan' toegekend. Binnen het bestemmingsvlak met die aanduiding waren al tien woningen gerealiseerd. De Afdeling oordeelt - kort samengevat - dat de aanvraag die als eerste was ingediend, paste binnen het bestemmingsplan (het betrof immers de elfde woning) en daarop de reguliere procedure van toepassing was, maar dat voor de tweede, latere aanvraag de uitgebreide procedure gold, omdat deze in strijd was met het bestemmingsplan. Volgens de Afdeling moet de planwetgever hebben bedoeld dat voor de vraag welke woning als elfde woning moet worden aangemerkt het moment van indienen van een aanvraag bepalend is. Een andere lezing zou namelijk kunnen leiden tot een willekeurige volgorde van behandeling van binnengekomen aanvragen. Volgens Widdershoven is sprake van een schaarse omgevingsvergunning, waarbij de vergunningen zijn verleend op grond van de verdeelmethode 'volgorde van de binnenkomst van de aanvragen'. 38

In bestemmingsplannen wordt - zoals in paragraaf 2.2 al aan de orde kwam - vaak expliciet het maximumaantal evenementen dat op een evenementenlocatie mag plaatsvinden vastgelegd. $\mathrm{Zo}_{\mathrm{o}}$ is in het bestemmingsplan voor het Museumplein in Amsterdam bijvoorbeeld bepaald dat op het museumplein maximaal zes grote evenementen (> 2000 bezoekers/deelnemers) per jaar mogen

\footnotetext{
6. Conclusie A-G 6 juni 2018, ECLI:NL:RVS:2018:1847 ABRvS 7 juni 2017, ECLI:NL:RVS:2017:1495.

38. Zie hierover ook A. Drahmann, Gelijke kansen bij het verlenen van schaarse vergunningen in het omgevingsrecht, TBR 2017/156.
} 
plaatsvinden en dat de maximale duur per evenement drie dagen op het gras bedraagt, waarna niet binnen twee weken een nieuw evenement op het gras kan plaatsvinden. In het licht van de conclusie van Widdershoven is het de vraag of hierdoor sprake is van een schaars recht. De eerste zes evenementen passen immers in het bestemmingsplan, maar voor het zevende evenement is een omgevingsvergunning vereist. In het verlengde hiervan is dan ook de vraag hoe die bestemmingsplanregels zich verhouden tot het beleid voor evenementenvergunningen. In Amsterdam is ook in het beleid door middel van locatieprofielen vastgelegd dat op het Museumplein slechts zes grote evenementen per jaar mogen plaatsvinden. Bepaald is dat voor 1 december van elk jaar voor grote evenementen een vooraanmelding moet worden ingediend. Als het aantal aangemelde evenementdagen het toegestane aantal overschrijdt, worden de vooraanmeldingen beoordeeld aan de hand van in de beleidsregels opgenomen criteria. ${ }^{39}$ In de volgende paragraaf wordt verder ingegaan op de vraag hoe schaarse evenementenvergunningen toegedeeld zouden kunnen worden.

\section{Gevolgen van schaarste bij evenementenvergunningver- lening}

In de vorige paragrafen is geconstateerd dat een evenementenvergunning schaars kan zijn. Op grond van het gelijkheidsbeginsel (het beginsel van gelijke kansen) moeten gemeenten dan ook vooraf vaststellen op welke wijze en op grond van welke criteria deze schaarse vergunningen zullen worden verdeeld. In deze paragraaf zal worden stilgestaan bij twee aspecten die relevant zijn bij de verdeling van vergunningen, namelijk (1) de verdeelmethode en (2) de duur van de vergunning.

\subsection{De verdelingsprocedure}

In de vorige paragraaf werd als voorbeeld kort het Museumplein in Amsterdam genoemd. Van dat plein is relatief voorzienbaar dat meer dan zes partijen daar een grootschalig evenement zouden willen organiseren. Het is dan ook niet verrassend dat de burgemeester hiervoor een procedure heeft vastgesteld, waarbij de aanvragen één keer per jaar worden beoordeeld op basis van kwalitatieve criteria. Dit wordt ook wel een 'tenderprocedure' genoemd.

Voor andere locaties, bijvoorbeeld in kleinere gemeenten, kan een dergelijke procedure onnodig complex zijn, bijvoorbeeld omdat zich daar tot op heden nog nooit de daadwerkelijke schaarste heeft voorgedaan. In dergelijke

39. Deze criteria zijn: geschiktheid op locatie, lokale binding, bijdragen aan kernwaarden 'creatief en innovatief' en bijdragen als maatschappelijk verantwoord ondernemerschap. Daarnaast geldt specifiek voor het Museumplein dat er in principe voorrang wordt gegeven aan evenementen door de instellingen rondom het plein zelf. gevallen staat er niets aan in de weg om wat vaak de huidige praktijk is te blijven voortzetten. Dit is immers feitelijk het systeem van 'wie het eerst komt, het eerst maalt': degene die als eerste een aanvraag indient, krijgt de evenementenvergunning. Ook bij deze verdeelmethode is het echter wenselijk om in een beleidsregel vast te leggen hoe de vergunningen worden toegedeeld, bijvoorbeeld vanaf wanneer aanvragen kunnen worden ingediend. Het zou immers onwenselijk zijn als een partij nu al aanvragen zou indienen voor een evenement dat pas over twee jaar of nog later plaatsvindt, alleen maar om zeker te stellen dat zij de eerste is. ${ }^{40}$ Daarnaast moet de burgemeester zich realiseren dat als er eenmaal expliciet voor gekozen is om de aanvraagdatum leidend te laten zijn, achteraf de aanvragen niet meer alsnog onderling vergeleken kunnen worden op kwaliteit. ${ }^{41}$

Een andere verdeelmethode is de loting. Deze verdeelmethode kan geschikt zijn als de burgemeester geen voorkeur heeft tussen de diverse aanvragen die allemaal aan de in de APV gestelde eisen voldoen. In paragraaf 2 is al gewezen op de prioriteitsvolgorde die de burgemeester van de gemeente Leiden hanteert. Als meerdere aanvragen voor dezelfde locatie tijdens hetzelfde dagdeel worden ingediend, wordt de volgende prioriteitsvolgorde bij de vergunningverlening gehanteerd: (1) bepaalde bij naam genoemde organisaties en evenementen, zoals de Oranjevereniging op Koningsdag, (2) evenementen met evenementensubsidie, (3) oud voor nieuw en (4) loting. ${ }^{42}$ De loting is hier dus een vierde en laatste middel om de rangorde te bepalen.

In sommige gevallen kan ook rouleren een denkbare verdeelmethode zijn. Als de evenementenvergunning ziet op bijvoorbeeld een podium met bar tijdens Koningsdag, op een plein waar meerdere horecaondernemers zijn gevestigd, is niet ondenkbaar dat het recht om dat evenement te organiseren periodiek rouleert tussen alle ondernemers die zijn gevestigd aan dat plein. In dat geval zal wel moeten worden gemotiveerd waarom de mededinging wordt beperkt tot die horecaondernemers aan het plein en niet openstaat voor eenieder. ${ }^{43}$

Een laatste mogelijkheid die ik hier noem, kan de 'verdeling op afroep' zijn. Een voorbeeld hiervan zijn vergunningen die worden verleend op grond van de Mijnbouwwet. De Mijnbouwwet bepaalt dat zodra een aanvraag om een vergunning is ingediend, anderen in de gelegenheid worden gesteld om aanvragen om een soortgelijke vergunning in te dienen voor dezelfde delfstof voor hetzelfde gebied. Voor de evenementenvergunningverlening zou dit betekenen dat als na de kennisge-

40. Zie over dergelijke 'vroegtijdige' aanvragen ook CBb 12 maart 2012, ECLI:NL:CBB:2012:BW0420, AB 2012/147 m.nt. C.J. Wolswinkel en CBb 15 februari 2012, ECLI:NL:CBB:2012:BV7097, AB 2012/148.

41. Vgl. CBb 8 januari 2010, ECLI:NL:CBB:2010:BL3125, JB 2010/72 m.nt. C.J. Wolswinkel.

42. Art. 6 van de Beleidsregel van de burgemeester van de gemeente Leiden houdende regels omtrent evenementenvergunningen Beleidsregels evenementenvergunningen 2017.

43. Zie voor een voorbeeld van een rouleersysteem CBb 12 maart 2012, ECLI:NL:CBB:2012:BW0420, AB 2012/147 m.nt. C.J. Wolswinkel. 
ving van de ingediende aanvraag geen tweede aanvraag wordt ingediend, de eerste aanvraag kan worden ingewilligd. Als wel een concurrerende aanvraag wordt ingediend, dan zal de burgemeester een keuze tussen die aanvragen moeten maken. Een voordeel van deze verdeelmethode kan zijn dat niet geinvesteerd hoeft te worden in bijvoorbeeld een tenderprocedure als de verwachting is dat er toch niet een tweede, concurrerende aanvraag wordt ingediend.

Uit het voorgaande blijkt dat er verschillende verdeelmethodes denkbaar zijn. Welke methode geschikt is, is maatwerk en zal per gemeente (en wellicht ook per locatie) verschillen. Ook combinaties van methodes zijn mogelijk. Voor gemeentebesturen is het de uitdaging om verdeelregels vast te stellen die enerzijds recht doen aan het gelijkheidsbeginsel, maar anderzijds de uitvoeringslasten voor zowel de gemeente als de (potentiële) aanvragers zo veel mogelijk beperken.

\subsection{De duur van de vergunning: voorrang voor bestaande evenementen?}

$\mathrm{Bij}$ evenementen is het niet ongebruikelijk dat sprake is van jaarlijks terugkerende evenementen. In evenementenbeleid is vaak vastgelegd dat die evenementen voorrang hebben boven nieuwe initiatieven. De vraag is hoe dit zich verhoudt met het gelijkheidsbeginsel. Zowel uit de Dienstenrichtlijn als uit de Vlaardingen-uitspraak blijkt immers dat schaarse vergunningen niet voor onbepaalde tijd mogen worden verleend.

Een evenementenvergunning is vaak maar geldig voor een beperkte tijd, namelijk de duur van het evenement. Het jaarlijks 'automatisch' opnieuw verlenen heeft tot gevolg dat de facto sprake is van een vergunning voor onbepaalde tijd. Dit is in strijd met het eerdergenoemde gelijkheidsbeginsel. Omdat een evenementenvergunning nu vaak maar geldig is voor dat ene evenement zou dit betekenen dat na het verstrijken van de geldigheidsduur van de vergunning, en dus na het evenement, de vergunning weer beschikbaar komt en de burgemeester mededingingsruimte zou moeten bieden. Het lijkt mij echter voor alle betrokken partijen onwenselijk als er jaarlijks verdeelprocedures gehouden zouden moeten worden. Dit zou voor zowel de gemeente als de aanvragers onnodig veel tijd en geld kosten. Daar komt nog bij dat een organisatie bij een commercieel evenement vaak ook de intentie heeft om het evenement meerdere jaren te organiseren, omdat het dikwijls tijd kost om een bepaalde reputatie op te bouwen en om de gedane investeringen terug te verdienen. Een belangriike reden om een vergunning telkens opnieuw te willen verlenen, is dat dan een aanvraag geweigerd zou kunnen worden als het jaar ervoor het evenement niet goed verlopen is. Hieraan kan echter tegemoet worden gekomen door het formuleren van intrekkingsgronden en door in de verordening en/of het beleid op te nemen dat de automatische verlenging niet onbeperkt is in tijd. In de vergunning, de verordening of de beleidsregels moet expliciet worden opgenomen dat een evenement (mits het voldoet aan alle eisen voor vergunningverlening) slechts een bepaald aantal jaren - bijvoorbeeld vijf of tien jaar - op een rij mag worden georganiseerd, maar dat dan een nieuw beoordelingsmoment plaatsvindt waarbij ook eventuele derden een mogelijkheid krijgen om voor een evenement op die locatie en op dat tijdstip een anvraag in te dienen. Door dit vooraf transparant vast te leggen heeft de vergunninghouder voldoende zekerheid dat hij in beginsel meerdere jaren zijn evenement mag organiseren, maar ook dat dit recht niet onbeperkt is.

\subsection{Uitzondering voor niet-commerciële evenementen?}

Bij (jaarlijks terugkerende) evenementen kan onderscheid worden gemaakt tussen commerciële en nietcommerciële evenementen. Bij een commercieel evenement kan worden gedacht aan muziekfestivals waarvoor entree wordt gevraagd en bij een niet-commercieel evenement aan een sinterklaasintocht. In de eerdergenoemde Nota evenementen van de gemeente Boxmeer is bepaald dat evenementen van niet-commerciële partijen in principe voorrang hebben op evenementen van commerciële partijen. Het is de vraag in hoeverre bij het verlenen van schaarse evenementenvergunningen rekening kan worden gehouden met dit niet-commerciële karakter.

Allereerst is van belang dat het aanvaarden van een uitzondering op de verplichting om mededingingsruimte te creëren afbreuk doet aan het gelijkheidsbeginsel. Hier moet dan ook terughoudend mee om worden gegaan. Het gelijkheidsbeginsel en de daaruit voortvloeiende transparantieverplichting vloeien voort uit jurisprudentie van het Hof van Justitie. ${ }^{44}$ Daarom is het interessant om te bezien welke beperkingen in het Unierecht aanvaardbaar worden geacht. Het Hof van Justitie heeft een beperking mogelijk geacht als zij wordt gerechtvaardigd door een dwingende reden van algemeen belang en die beperking proportioneel (geschikt en noodzakelijk) is met het oog op die reden. Een voorbeeld hiervan is de zaak CASTA, waarin een opdracht voor het verrichten van medische vervoersdiensten (ambulancevervoer) rechtstreeks en zonder enige vorm van bekendmaking werd gegund aan vrijwilligersorganisaties. Dit was volgens het Hof van Justitie mogelijk, mits het wettelijk en contractuele kader waarbinnen die organisaties werken 'daadwerkelijk bijdraagt aan het sociaal doel en aan de doelstellingen van solidariteit en kostenefficiëntie'. ${ }^{45}$ In het verlengde hiervan lijkt het dus mogelijk om in (beleids)regels vast te leggen dat evenementen van nietcommerciële organisaties, bijvoorbeeld vrijwilligersorganisaties en lokale organisaties, voorrang krijgen. Wel zal in de toelichting moeten worden gemotiveerd waarom het gerechtvaardigd is dat die organisaties voorrang krijgen en daarmee de mededingingsruimte wordt beperkt. Concreet zou deze uitzonderingsgrond toe te passen zijn bij lokale stichtingen en verenigingen die sinds jaar en dag bepaalde evenementen organiseren, zoals de sinter-

44. Aldus ABRvS 12 april 2017, ECLI:NL:RVS:2017:994, AB 2017/300 m.nt. C.J. Wolswinkel.

45. HvJ EU 28 januari 2016, C-50/14, ECLI:EU:C:2016:56 
klaasintocht en Oranjeverenigingen. Daarbij verdient het wel de voorkeur dat als die vereniging of stichting (al dan niet in overleg met de gemeente) bepaalde (markt)partijen selecteert - bijvoorbeeld wie op welk podium mag staan -, die stichting of vereniging (waar mogelijk) het gelijkheidsbeginsel in acht neemt. Deze reflexwerking van het gelijkheidsbeginsel zou kunnen worden geborgd via het evenementenbeleid of de subsidieverlening.

Ook is het mogelijk een (exploitatie)vergunning onderhands te verlenen aan een exploitant op wiens activiteiten de overheid een strenge controle uitoefent. ${ }^{46}$ Niet uitgesloten is dan ook dat als sprake is van quasi-inbesteding, die overheidsstichting een voorrangsrecht mag krijgen.

Ten derde wordt in het aanbestedingsrecht een uitzondering aangenomen als sprake is van artistieke of technische uniciteit. In dat geval moet vaststaan dat een bepaalde dienst alleen kan worden verricht door een bepaalde ondernemer. Er zijn aanknopingspunten dat in het nationale bestuursrecht een ruimere interpretatie wordt gegeven aan het begrip 'uniciteit' en dat een vergunning ook zonder transparante verdeelprocedure verleend kan worden als bij voorbaat vaststaat dat er slechts één gegadigde is die aan de voorwaarden van de APV kan voldoen. ${ }^{47}$

Ten slotte is in het aanbestedingsrecht beperking mogelijk in geval van dwingende, onvoorzienbare spoed. Gelet op de termijn waarop evenementenvergunningen normaliter moeten worden aangevraagd, zal hiervan niet snel sprake zijn, maar deze uitzondering zou wellicht toegepast kunnen worden als Nederland op enig moment weer in de finale van het $\mathrm{EK}$ of $\mathrm{WK}$ voetbal staat en een evenementenvergunning wordt verleend om buiten op een groot scherm naar de wedstrijd te kunnen kijken.

In het voorgaande is in het algemeen gesproken over uitzonderingen op de verplichting om mededingingsruimte te creëren. Voor de leesbaarheid heb ik daarbij slechts beperkt onderscheid gemaakt tussen de uitzonderingen die het Unierecht, de Dienstenrichtlijn en het nationale recht bieden. Gelet op de recente datum van de Vlaardingen-uitspraak is hierover nog geen jurisprudentie beschikbaar. Het is enerzijds mogelijk dat, omdat sprake is van een nationaal beginsel, de bestuursrechter een uitzondering eerder niet onredelijk zal achten. Anderzijds zouden in dat geval het Unierechtelijke toetsingskader en het nationaalrechtelijke toetsingskader verder uiteenlopen, hetgeen de toepassing van het gelijkheidsbeginsel bij de verdeling van schaarse vergunningen in de praktijk ook niet zou vergemakkelijken. Bovendien is in dit kader van belang dat de evenemen-

46. HvJ EU 3 juni 2010, AB 2011/17 m.nt. A.W.G.J. Buijze, JB 2010/171 m.nt. C.J. Wolswinkel.

47. Vgl. ABRvS 27 september 2017, ECLI:NL:RVS:2017:2611, AB 2017/389 m.nt. C.J. Wolswinkel. Zie tevens conclusie A-G in de Vlaardingen-zaak, alinea 6.1-6.18 (AB 2016/426 m.nt. C.J. Wolswinkel). tenvergunning mogelijk onder het toepassingsbereik van de Dienstenrichtlijn valt, waardoor uitzonderingen moeten voldoen aan het Unierechtelijke evenredigheidsbeginsel. ${ }^{48}$

Samenvattend lijkt het dus mogelijk om in de APV dan wel beleidsregels vast te leggen dat evenementen van niet-commerciële organisaties, bijvoorbeeld vrijwilligersorganisaties en lokale organisaties, voorrang krijgen boven commerciële evenementen. Wel zal in de toelichting moeten worden gemotiveerd waarom het gerechtvaardigd is dat die organisaties voorrang krijgen en daarmee de mededingingsruimte wordt beperkt. Daarnaast lijkt het wenselijk om ook deze voorrangspositie te beperken in de tijd, zodat periodiek kan worden bezien of de beperking van de mededingingsruimte in deze vorm nog wel gerechtvaardigd is.

\section{Afronding}

In dit artikel heb ik de vraag willen beantwoorden of bij het verlenen van een evenementenvergunning sprake kan zijn van een schaarse vergunning. Deze vraag moet volgens mij bevestigend worden beantwoord. Dit kan het geval zijn als meerdere aanvragen worden ingediend voor een evenement op dezelfde plek en op hetzelfde tijdstip en (bijvoorbeeld vanwege de openbare veiligheid) slechts één vergunning kan worden verleend. Ook kan sprake zijn van een schaarse vergunning als het evenementenbeleid en/of het bestemmingsplan een maximum stellen aan het aantal evenementen dat per jaar op een bepaalde locatie mag plaatsvinden.

Zowel de Dienstenrichtlijn als het nationale recht stelt eisen aan de verlening van een dergelijke beleidsmatig schaarse vergunning. Dit betekent dat de burgemeester beleidsregels zou moeten vaststellen waaruit blijkt hoe voor een schaarse vergunning in aanmerking kan worden gekomen. Dergelijke beleidsregels vergen maatwerk, waarbij zowel een verdeling op volgorde van binnenkomst van de aanvragen als een beoordeling van de aanvragen op hun onderlinge kwaliteit mogelijk is. Ook kunnen schaarse vergunningen in beginsel niet voor onbepaalde tijd worden verleend. De onbeperkte automatische verlening van een evenementenvergunning voor jaarlijks terugkerende evenementen valt hier ook onder en zou dan ook vervangen moeten worden voor een systeem waarbij die automatische voorrangspositie wordt beperkt in de tijd. Ten slotte kan voor evenementen van niet-commerciële organisaties wellicht een (beperkte) uitzonderingspositie worden aanvaard, maar in dat geval zullen de noodzaak en proportionaliteit van die uitzondering wel moeten worden gemotiveerd.

In veel gemeenten zullen zich tot op heden geen verdeelvraagstukken hebben voorgedaan bij de verlening

48. Zie over het Unierechtelijke evenredigheidsbeginsel onder meer Van Oosten \& Drahmann 2018. 
van evenementenvergunningen. Door de recente ontwikkelingen op het gebied van schaarse vergunningen en de Dienstenrichtlijn zal dit echter naar verwachting veranderen. Het in de inleiding gegeven voorbeeld over het carnavalsfeest laat zien dat een burgemeester zich onverwacht geconfronteerd kan zien met twee aanvragen waaruit een keuze gemaakt moet worden. Het verdient aanbeveling dat gemeenten deze situatie voor zijn en hierop in hun beleidsregels anticiperen door verdeelregels op te stellen. 